\title{
ASSESSING THE SOCIAL AND ECONOMIC BENEFITS OF ORGANIC AGRICULTURE CONVERSION
}

\author{
Fajar Setiawan ${ }^{1}$, Rizki Kharina Dewi ${ }^{2}$, Hendrik Widiyanto ${ }^{3}$ \\ ${ }^{1}$ Bank Indonesia Regional Office of Lhokseumawe, Aceh, Indonesia \\ ${ }^{2}$ Indonesian Public Listed Companies Association, DKI Jakarta, Indonesia \\ ${ }^{3}$ Faculty of Economics and Business, Diponegoro University, Indonesia
}

\begin{abstract}
Unsustainability of conventional agriculture practices led to the increase of conversion to organic agriculture. This study investigates farmers' personal motive of conversion and examine the significance of conversion period in organic agriculture practice. This study further analyses social and economic benefits of conversion to organic agriculture and its contribution in increasing sustainable rural development in Indonesia. This study uses mixed method analysis by conducting qualitative and quantitative data collection strategy. This study uses purposive sampling approach and further determined Getasan Organic Agriculture as main case study. The findings suggest that farmers' personal motive on conversion mainly revolves around environmental concerns. Furthermore, this study found that farmers considered conversion period as opportunity costs that will result in higher social and economic benefit. Lastly, this study found that organic agriculture practice is beneficial socially and economically and is expected to be more attractive in the future.
\end{abstract}

Keywords: Organic agriculture, conversion period, motives on conversion, sustainable development.

\section{INTRODUCTION}

$$
\text { History of agricultural }
$$

development in Indonesia started with modernized agriculture system through Green Revolution Program in the 1960s. The program emphasized agricultural development through massive and intensive technology on high-yielding agricultural products
(Ariesusanty, 2011). Technology adopted in Green Revolution highly utilize chemical inputs such as pesticides and fertilizers, as well as appliance of several combination of agricultural techniques. The program successfully increased overall agricultural in the short term. However, increased agricultural 
productivity in Green Revolution Program was not permanent. Longterm use of chemical fertilizers and pesticides induced massive soil degradation in Indonesia. In the 1980s, productivity of agricultural sector decreased by eight percent annually (BPS, 2000). Excessive use of chemical inputs in conventional agriculture practice further imposed adverse effect on environment in Indonesia, which result in unsustain agricultural development. Therefore, conventional agriculture practice in Green Revolution program result in unsustainable development.

Accordingly, increasing awareness towards sustainable development has led to the increase of organic agriculture practices in Indonesia. Organic agriculture practices in Indonesia firstly started in the early 1980s through organic farmers' initiatives in coping with massive soil degradation (David \& Ardiansyah, 2017). Organic agriculture specifically minimizes external chemical input, such as chemical pesticides and fertilizers due to its aim on achieving sustainable agricultural production (Casagrande et al., 2016). Organic agriculture also emphasizes its practice on natural process of agriculture through crop rotations and ecological procedure that will boost agricultural productivity without deteriorating soil productivity (Leifeld, 2012). Existing literature suggested that organic agriculture practices result in wide range of benefits. Studies of Lobley \& Potter (2004), Zulfiqar \& Thapa (2017), Berbeć et al. (2018) suggested that organic agriculture improved environmental benefits, social and economic benefits, as well as increasing regional economies. Additionally, organic agriculture may impact sustainable rural development through rural labour absorption (Mohamed Haris et al., 2018).

Despite beneficial return of organic agriculture, conversion to organic agriculture involved complicated procedure. Conversion to organic agriculture normally require major effort in neutralizing organic agricultural system (David \& Ardiansyah, 2017). Early stages of conversion naturally imposed higher costs and risks on farmers. Accordingly, decision on conversion 
specifically rely on farmers' personal motives. However, recent studies on organic agriculture in Indonesia merely focused on economic and ecological aspects (David \& Ardiansyah, 2017; Rahmawati et al. 2015; Slamet et al. 2016), while it is important to address farmers' personal motives on conversion to further promote organic agriculture development in Indonesia. Furthermore, discussions regarding conversion period is limited, while it is important to highlight the economic return of conversion period to provide deeper understanding on organic agriculture practice. Therefore, to fill the gap in existing literature, this study would like to address farmers' personal motives and conversion period of organic agriculture in Indonesia.

Thus, the main objective of this study is to investigate farmers' personal motives of conversion and to understand significance of conversion period in organic agriculture practice. This study would further assess social and economic benefits of conversion and analyse the contribution to sustainable rural development. to organic agriculture in Indonesia. Hence, this study uses qualitative and quantitative method to analyse the issues intensively. We conduct case study analysis on small-scale agricultural practice by considering to the characteristic of organic practices in Indonesia. The study is structured as follows. Section two reviews existing literature on organic agriculture. Section three describes methodology and data collection strategy. Section four contains results and discussion of the study. Finally, section five draws conclusions of the study.

\section{LITERATURE REVIEW}

Prominent findings suggest that conventional agriculture is likely to be the source of environmental problems due to excessive use of synthetic chemical inputs (Conway, 1985; Gomiero et al., 2011; Zulfiqar \& Thapa, 2017). Conventional agriculture has adverse health effect and further escalates natural degradation, such as soil degradation and the increase of ground water contamination (Rasul \& Thapa, 2004). Additionally, excessive use of 
synthetic chemical inputs resulted in higher production costs, while product deterioration is inevitable in the long run (Zia et al., 2009). Therefore, current studies focus on emphasizing sustainable agriculture practices to tackle the detrimental outcome of conventional agriculture.

$$
\text { Considering problems }
$$

associated with conventional agriculture, studies have promoted organic agriculture globally due to its beneficial impact on sustainable development (Mohamed Haris et al., 2018). Organic agriculture is defined as agricultural practice that involves economics, social, and environmental aspects within production (Gomiero et al., 2011; Qiao et al., 2016). Consequently, conversion to organic agriculture practices is further encouraged.

Studies on organic agriculture commonly used economic theory approaches. Wynn et al. (2008) developed multinomial logit model and duration analysis in estimating probability and rate of farmers entry on organic agriculture in Scotland. Lobley et al. (2009) analysed the nature of organic agriculture and its implications on rural development in England and Wales. Mohan Kumar et al. (2017) and Vasile et al. (2015) developed comparative study in analysis economic efficiency of organic agriculture compared to conventional agriculture practice. Both studies highlight the attractiveness and feasibility of organic agriculture for small-scale agriculture practice. Qiao et al. (2016) developed qualitative study in assessing social and economic benefits of organic agriculture in China and Sri Lanka. While studies of Berbeć et al. (2018) specifically employed RISE (Response-Inducing Sustainability Evaluation) indicator on organic and low-input conventional agriculture practices. This study further emphasized sustainability of organic and lowinput conventional agriculture in the long run.

Moreover, other strand of studies considered varieties of socioeconomic and behavioural approach as motives of farmers in conversion to organic agriculture. Mohamed Haris et al. (2018) developed mixed method analysis in estimating the adoption of 
organic agriculture in respect to socio-economic, social, and attitude as key factors. The result of the study indicated that environmental attitudes as the most influential factor, followed by knowledge sharing, and land ownership. Studies of Beban, (2014), Casagrande et al. (2016), Padel (2008), and Zulfiqar \& Thapa (2017) considered personal values, motives, attitude, and socio-economic perspective as main driver of conversion to organic agriculture. These studies found that environmental concerns and beliefs were considered as main motives for conversion to organic agriculture. Additionally, this study also emphasized that professional background, farm types, and external economic circumstances were significant influence for organic farmers' personal motives and values.

Remarkably, conversion to organic agriculture is complicated. Conversion to organic agriculture normally require several months of effort in neutralizing the whole agriculture system to restore natural soil productivity or as it is known as conversion period (FAO, 2015).
Conversion period implies lower profitability and high risks of production at the earlier stages of conversion to organic agriculture. Accordingly, the decision in conversion rely upon farmers' personal motives, values, and socioeconomic factors. However, discussions on conversion period were relatively rare, while we think that analysing farmers' motives and socio-economic driver on conversion during conversion period needs to be addressed further. Therefore, this study attempts to provide comprehensive study on conversion period in the analysis.

Despite growing concerns on organic agriculture, studies on organic agriculture in Indonesia is relatively rare. Compared to other countries, organic agriculture practices and policies in Indonesia were discussed infrequently. Thus, we provided organic agriculture practices and policies in Indonesia compared to other Asian countries as summarized in Table 1. Contrast to organic agriculture practices in other countries, Indonesia's organic agriculture was firstly initiated by 
community and NGOs. Organic agriculture was not promoted or initiated by the government, compared to the organic practices in Korea and India. Thus, farmers' motives on conversion needs to be addressed to further understand organic agriculture development in Indonesia. Therefore, we attempt to study farmers' personal motives of conversion to organic agriculture in Indonesia.

Table 1. Comparison of Organic Agriculture Practice and Policy in Asia

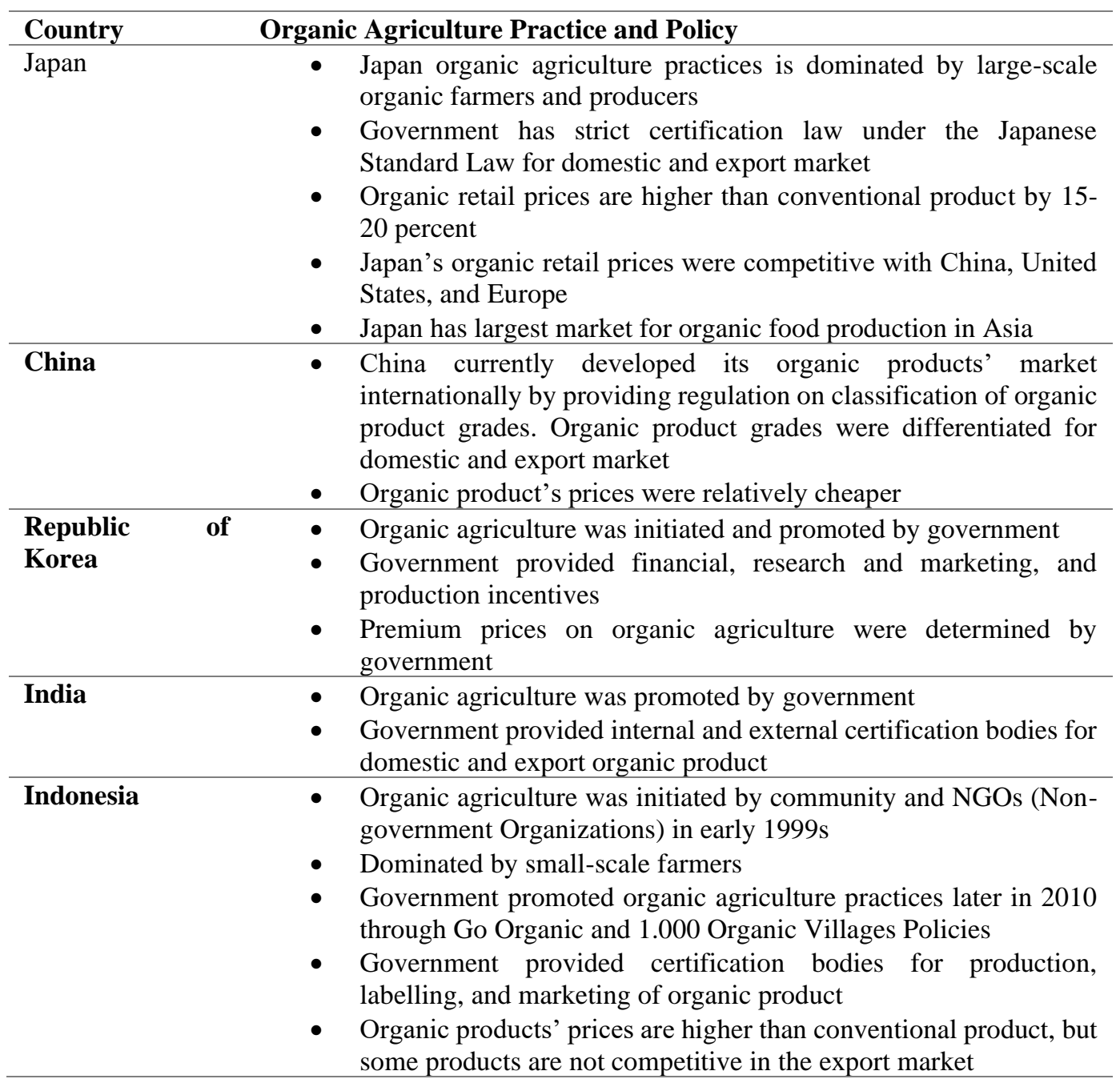

Source: Hsieh (1999), Ariesusanty (2011), Ashari et al. (2018), and David \& Ardiansyah (2017)

\section{METHODOLOGY}

The empirical work presented

in this study is based on five months

of fieldwork in 2019. Prior to data collection, we develop purposive sampling approach in determining the case study of organic agriculture practice in Indonesia. Based on the evidence that organic vegetable 
dominated organic product demand in Indonesia, we specifically selected Getasan Village, Semarang District, in Central Java which has the largest vegetable organic area and longest experience in organic farming in Indonesia (SPOI, 2016). Getasan organic agriculture practices were dominated by small-scale farmers, which produced $90 \%$ of overall organic vegetable product in Central $\mathrm{Java}^{1}$. Socio-economic characteristics of the organic vegetable producer in Getasan is summarized in Table 2. Therefore, the rationale for choosing Getasan as the main case study was based on the evidence as one of the largest organic vegetable producers in Indonesia which consists of smallscale organic vegetable producers.

Table 2. Socio-Economic Characteristics of Organic Vegetable Farmers in Getasan

\begin{tabular}{ll}
\hline Number of Samples & 63 \\
\hline Conversion Year & $2000-2002$ \\
\hline Household Size & 5.5 \\
\hline Farmers' Average Age & 35 \\
\hline Farm Size & $<1$ hectare \\
\hline Market Orientation & Domestic and Export \\
\hline Main Product & Broccoli, French beans, Baby kailan, etc. \\
\hline Organization & Cooperative and Village Farmers' Group \\
\hline
\end{tabular}

Source: Own data, 2018

Furthermore, we designed three stages of data collection that involves qualitative and quantitative data collection method. First, we conduct explanatory interviews with key actors, such as Agriculture Agency Staff, Cooperatives, Organic Farmers Organizations, and Certification Bodies. Secondly, we implement purposive sampling approach and questionnaire in gathering qualitative and quantitative

${ }^{1}$ Getasan Village is located on the slope of Merbabu Mountain with average altitude of datasets on 63 organic farmers regarding perception on conversion to organic agriculture and detailed production data. Finally, we conducted focus group discussion (FGD) with five farmer groups to collect additional qualitative data regarding organic agriculture conversion practice. Essentially, this study focuses on organic agriculture practice and the significance of

$1,350 \mathrm{~m}$ above sea levels and average temperature is $19^{\circ} \mathrm{C}$, which is suitable for vegetable agriculture practices (BPS, 2015) 
conversion period without discussing other agriculture practices.

\section{RESULTS AND DISCUSSION}

Main objective of this study is to investigate farmers' personal motives on conversion to organic agriculture and understand the relevance of conversion period in organic agriculture practices in Indonesia. This study also aims to assess the economic and social benefits of organic agriculture practice in Indonesia and its contribution on sustainable rural development. As discussed in the previous section, we specifically conduct semi-structured interviews followed with FGD on five farmer groups. Results of the study are as follows.

Farmers' personal motives for conversion to organic agriculture in Getasan are summarized in Table 3. Personal motives identified through semi-structured interviews and FGD include various aspects, such as environmental protection, health issues, sustainability, product quality, production costs, rural employment, and regeneration. To provide deeper understanding regarding farmers' personal motives on conversion, we also provide farmers' level of priorities as it is summarized in Table 3.

Farmers' Personal Motives for Conversion

Table 3. Personal Motives on Conversion

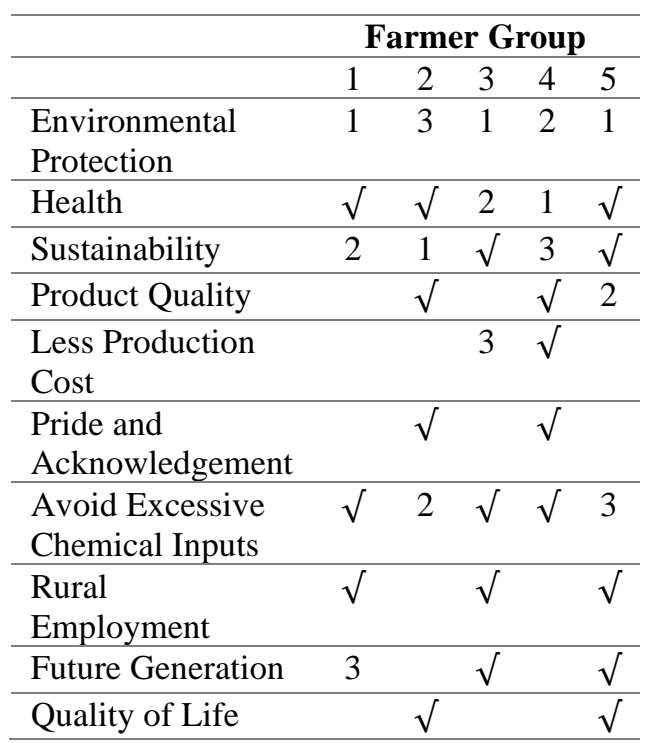

Note: The three most important motives were marked 1-3 according to farmers' personal priorities. Other important motives were marked with $\sqrt{ }$

Source: Own data, 2018

The result of this study suggests that farmers mainly establish environment protection as main motive for conversion to organic agriculture in Getasan. This result is to be expected, since Getasan farmers experienced tremendous soil degradation in early 1999s as the aftermath of conventional agriculture practice. This phenomenon further 
encouraged Getasan farmers to convert on organic agriculture as stated by a farmer, as follows:

"Conventional agriculture practices with excessive chemical fertilizer and pesticides induced gradual soil graduation. Soil degradation firstly started in the early 1990s and only worsen by the end of 1999s. We experienced sever soil degradation which result in unproductive and unprofitable agriculture practices. Most farmers became unemployed and unproductive for months. Accordingly, we decided to convert on agriculture practice in the early 2000s." - (Organic Farmer 1)

The result is in line with previous findings of Gomiero et al. (2011), Mohamed Haris et al. (2018), Padel (2008), Beban, (2014), Casagrande et al. (2016), and Zulfiqar \& Thapa (2017) which emphasized the significant role of environment as the main driver for conversion to organic agriculture. Thus, the result emphasized environment and health aspect as the most influential motive for conversion.

Beside central discussion on environmental issues, farmers emphasized the importance of

2 Gibbons and Schroeder. (1983). Agricultural Extension. Accessed in http://www.nzdl.org/gsdlmod?e economic and social benefits, rural employment, sustainability, pride and acknowledgement, and personal needs for regeneration in agriculture practices as motives for conversion. Lower production costs and increasing product quality are considered as social and economic benefits of organic agriculture which further encourage conversion in Getasan. The result is in line with Padel (2008) which concluded that changes in agricultural practices may vary, but strongly influenced by farmers' personal motives and background. Small-scale farmers in organic agriculture practices tend to rely on the activities of the rural area, hence result in personal concerns on regeneration, acknowledgement, and sustainable rural development. This result supported findings of Gibbons and Schroeder (1983) which highlighted small-scale farmers' personal motives on rural development ${ }^{2}$. 


\section{Conversion Period}

To examine conversion period on organic agriculture practice in Getasan, we conducted explanatory interviews with farmers, Agriculture Agency Staff, and Organic Farmers Organization. As a result, procedure of conversion period in Getasan is summarized in Figure 1. Figure 1 shows that farmers experienced four stages of conversion to fully implement organic agriculture. Each stage normally includes six months of conversion procedure. Firstly, farmers need to neutralize the whole agriculture system by cultivating orok-orok $^{3}$. During this stage, farmers focuses on increasing soil productivity. Afterwards, farmers started to conduct both plantation experiments and orok-orok cultivation in the second, third, and fourth stage of conversion period. Plantation experiments were meant to stimulate farmers' learning and experiments on agriculture practices and generate income.

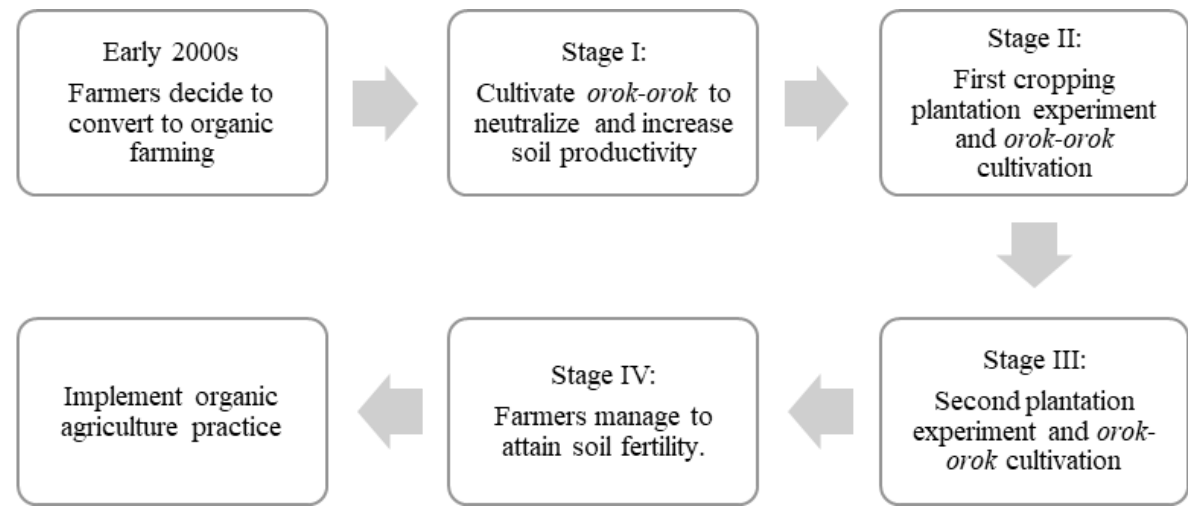

Figure 1. Conversion Procedure of Organic Agriculture (Case Study: Getasan) Source: Own data, 2018

To further analyse the significance of conversion period in organic agriculture practice, we provided economic valuation of conversion as summarized in Table 3.

3 Orok-orok (Crotalaria juncea) increases soil fertility. Orok-orok plantation required
Economic valuation in this study covers two period of analysis, which consists of four stages of conversion period and the implementation of organic agriculture in Getasan. The

regularly crop rotation intervals (Rotar \& Joy, 1983). 
result shows that total costs were relatively higher during the early stages of conversion, nonetheless, net benefits started increasing after the second stage of conversion period. Furthermore, this finding supports the main ideas of farmers' personal economic motive on conversion, which highlights economic benefits of organic agriculture in the foreseeable future. This implies that farmers willingly endure opportunity costs and economic risks at the early stages of conversion in return to higher net benefits yielded in the future.

Table 3. Economic Valuation of

Conversion Period

\begin{tabular}{|c|c|c|c|c|}
\hline & & $\begin{array}{l}\text { Total } \\
\text { Costs } \\
\text { (Rp) }\end{array}$ & $\begin{array}{l}\text { Revenue } \\
\quad(\mathrm{Rp})\end{array}$ & $\begin{array}{c}\text { Net } \\
\text { Benefit } \\
(\mathrm{Rp})\end{array}$ \\
\hline \multirow{4}{*}{$\begin{array}{c}\text { Conversion } \\
\text { Period } \\
\text { Stages }\end{array}$} & 1 & 49 & 0 & -49 \\
\hline & 2 & 4,055 & 2,775 & $-1,330$ \\
\hline & 3 & 2,097 & $2,756.5$ & 658.5 \\
\hline & 4 & $4,400.6$ & $5,137.5$ & 736.90 \\
\hline Organic & & 15,070 & 39,762 & 24,692 \\
\hline
\end{tabular}

Agriculture

Note: Total costs, revenue, and net benefits are in thousand rupiahs. Total costs and revenues are calculated with yearly average prices. Conversion period is calculated according to conversion procedure in Figure 2.

Source: Own data, 2018

Furthermore, it is arguable that farmers preferred to bear lower profits in the early stages of conversion rather than experiencing gradual degradation during conventional agriculture practice. This result is in line with our previous findings, which emphasized farmers'strong environmental concerns as main driver of conversion to organic agriculture. This result is in line with existing studies of Mohamed Haris et al. (2018), Rasul \& Thapa (2004), Vasile et al. (2015), Wynn et al. (2008), Beban (2014), Casagrande et al. (2016), and Padel (2008).

Economic and Social Benefits of Conversion

Comprehending the importance of conversion to organic agriculture, we employ economic and social benefit analysis of conversion in this study. We use quantitative and qualitative datasets on organic agriculture practices in deriving economic and social benefits of conversion.

Cost structure and economic benefits of organic agriculture in Getasan is shown in Table 4. Costs and returns were analysed based on fixed costs and depreciation, variable costs such as wage, seeds, natural 
fertilizers, water, and land rent. Costs were calculated on average market prices under the assumption that inflation is zero. Gross revenue and return were determined based on farmers' income on production. Economic benefit of conversion is further calculated with Benefit-Cost Ratio Analysis (B/C Ratio Analysis).

Table 4. Economic Analysis of Organic Agriculture Practice in Getasan

Organic

Agriculture

\begin{tabular}{lc} 
& $(\mathrm{Rp})$ \\
\hline Variable Costs & $9,120,000$ \\
\hline $\begin{array}{l}\text { Fixed Costs } \\
\text { Depreciation }\end{array}$ & $5,950,000$ \\
\hline Total Cost & $15,070,000$ \\
\hline Revenue & $39,762,000$ \\
\hline Net Benefit & $24,692,000$ \\
\hline B/C Ratio & $\mathbf{1 . 6 4}$ \\
\hline
\end{tabular}

Note: economic analysis in this study is based on monthly total costs and revenues derived from organic agriculture practice in Getasan. Source: Own data, 2018.

Table 4 summarized the costs, revenue, net benefit, and $\mathrm{B} / \mathrm{C}$ ratio of organic agriculture practice in Getasan. B/C ratio result indicates that organic agriculture practice in Getasan is profitable and feasible. Therefore, this result highlights the feasibility of organic agriculture practice. The result suggests that organic agriculture practice is feasible and profitable. This implies that despite existing opportunity costs in the early stages of conversion, farmers will further earn economic net benefits in the long term. This result supported findings of Mohan Kumar et al. (2017) and Qiao et al. (2016).

In addition to economic benefits of organic agriculture, we also found social benefits of conversion through semi-structured interviews and focus group discussion (FGD). Our qualitative findings suggest that organic agriculture induce increases in rural employment opportunities. As it is evident in Figure 2, total labour input significantly increases during organic agriculture practices in Getasan. Total hired labour was approximately 2 times higher in the organic agriculture compared to conventional agriculture. Moreover, qualitative datasets suggest that organic agriculture encourages community development and increasing organizational capacity of farmers in Getasan. Environmentally friendly agriculture practices induced socio-economic and environmental development in the rural areas, which further encourage 
community development. It is also evident that farmers' organizational capacity increase significantly during organic practices due to comprehensive knowledge sharing and highly intensive technical production terms.

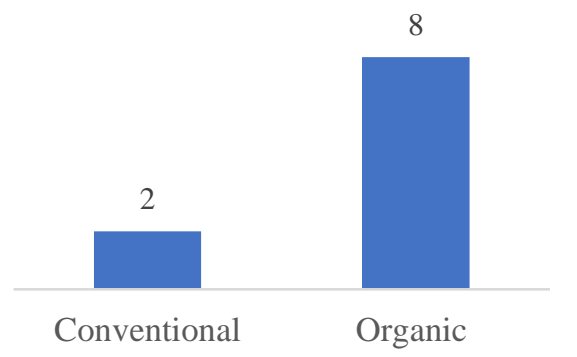

Figure 2. Use of Total Labour per Agriculture Production in Organic and Conventional Agriculture (Case Study: Getasan)

Note: Total labour presented in the study portrays average total labour in each agricultural production in Getasan. Average total conventional agriculture labour indicated total labour before conversion to organic agriculture.

Source: Own data, 2018

Essentially, economics and social benefits of conversion to organic agriculture for small-scale farmers is apparent in the case study. Direct economic and social benefits were certain in the agricultural practices. However, economics and social benefits were uncertain in terms of sustainable rural development. Despite increasing rural labour absorption, it remains unclear whether the phenomenon would further result in increasing rural per capita income or not. Thus, incorporating rural employment opportunities, land redistribution, knowledge sharing, agriculture infrastructure, and health and education services may be significant as part of comprehensive ruraldevelopment strategy.

\section{CONCLUSION}

Main finding of this study suggest that farmers perceived environmental concerns as the most influential motive that encourage farmers to convert to organic agriculture. This study further comprehends the significance of conversion period to fill the gap in existing literature. The economic valuation result indicated that total costs are relatively higher during the early stages of conversion, but net benefits increase after the second stage of conversion. This implies that economic benefits during conversion period is evident. Farmers also willingly bear opportunity costs during the early conversion period due to higher net benefits in the long 
term. Moreover, farmers preferred to endure opportunity costs in the early stages of conversion period rather than external costs induced in the conventional agriculture practice. Moreover, this study found that organic agriculture is economically and socially beneficial in practice. Net benefits and revenues of organic agriculture appear to be attractive.

The study also highlighted the relevance of organic agriculture practices and sustainable rural development. Despite unclear association between organic agriculture and rural development, it is evident that organic agriculture practice increases rural employment. Furthermore, environmentally friendly organic agriculture practices induced sustainable rural development. However, the findings may not be representative for all organic agriculture practices, but relevant to fill the gap in the existing literature and discussions regarding organic agriculture conversion.

Finally, policy implications indicated in the study revolve mainly on government's participation in developing organic agriculture in Indonesia. Government needs to provide agriculture infrastructure, incentives on research and financial support for organic farmers. Government also need to provide market access in establishing local organic product demand in Indonesia as well as developing international organic product demand.

\section{REFERENCES}

Ariesusanty, L. (2011). ASIA: COUNTRY REPORT INDONESIA Indonesia: Country Report. 2005-2007.

Ashari, N., Sharifuddin, N., \& Abidin, M. Z. (2018). Factors Determining Organic Farming Adoption: International Research Results and Lessons Learned for Indonesia. Forum Penelitian Agro Ekonomi, 35(1), 45. https://doi.org/10.21082/fae.v35 n1.2017.45-58

Beban, A. (2014). Is Organic Agriculture a Viable Strategy in Contexts of Rapid Agrarian Transition? Evidence from Cambodia. Journal of Agriculture, Food Systems, and Community Development, 4(2), 1-17. https://doi.org/10.5304/jafscd.2 014.042.004

Berbeć, A. K., Feledyn-Szewczyk, B., Thalmann, C., Wyss, R., Grenz, 
J., Kopiński, J., Stalenga, J., \& Radzikowski, P. (2018). Assessing the sustainability performance of organic and lowinput conventional farms from Eastern Poland with the RISE indicator system. Sustainability (Switzerland), 10(6). https://doi.org/10.3390/su10061 792

Casagrande, M., Peigné, J., Payet, V., Mäder, P., Sans, F. X., BlancoMoreno, J. M., Antichi, D., Bàrberi, P., Beeckman, A., Bigongiali, F., Cooper, J., Dierauer, H., Gascoyne, K., Grosse, M., Heß, J., Kranzler, A., Luik, A., Peetsmann, E., Surböck, A., ... David, C. (2016). Organic farmers' motivations and challenges for adopting conservation agriculture in Europe. Organic Agriculture, 6(4), 281-295. https://doi.org/10.1007/s13165015-0136-0

Conway, G. R. (1985). Agroecosystem analysis. Agricultural Administration, 20(1), 31-55. https://doi.org/10.1016/0309586X(85)90064-0

David, W., \& Ardiansyah. (2017). Organic agriculture in Indonesia: challenges and opportunities. Organic Agriculture, 7(3), 329338.

https://doi.org/10.1007/s13165016-0160-8

Gomiero, T., Pimentel, D., \& Paoletti, M. G. (2011). Environmental impact of different agricultural management practices:
Conventional vs. Organic agriculture. Critical Reviews in Plant Sciences, 30(1-2), 95124.

https://doi.org/10.1080/0735268 9.2011.554355

Hsieh, S. (1999). Organic Farming for Sustainable Agriculture in Asia With Special Reference To Taiwan Experience. Science And Technology, 1-30.

Leifeld, J. (2012). How sustainable is organic farming? Agriculture, Ecosystems and Environment, 150, 121-122. https://doi.org/10.1016/j.agee.20 12.01.020

Lobley, M., Fish, R., Butler, A., Courtney, P., Courtney, B., Ilbery, B., Kirwan, J., Maye, D., Potter, C., \& Winter, M. (2009). Analysis of socio-economic aspects of local and national organic farming markets. In University of Exeter/ ... (Issue 29).

http://www.safefoods.ir/Downlo ads/Papers/Analysis of socioeconomic aspects of local and national organic farming markets.pdf

Lobley, M., \& Potter, C. (2004). Agricultural change and restructuring: Recent evidence from a survey of agricultural households in England. Journal of Rural Studies, 20(4), 499510.

https://doi.org/10.1016/j.jrurstu d.2004.07.001

Mohamed Haris, N. B., Garrod, G., Gkartzios, M., \& Proctor, A. 
(2018). The Decision to Adopt Organic Practices in Malaysia ; a Mix-method Approach. 92nd Annual Conference, April 16-18, 2018, Warwick University, Coventry, UK, 1-21. https://econpapers.repec.org/pap er/agsaesc18/273485.htm

Mohan Kumar, M., Adarsha, L. K., Prakash Singh, S., \& Likin Boppana, K. (2017). Economics of Organic Farming over Conventional Farming- A Case Study in Karnataka, India. International Journal of Current Microbiology and Applied Sciences, 6(11), 2810-2817. https://doi.org/10.20546/ijcmas. 2017.611.331

Padel, S. (2008). Values of organic producers converting at different times: Results of a focus group study in five European countries. International Journal of Agricultural Resources, Governance and Ecology, 7(12), 63-77. https://doi.org/10.1504/ijarge.20 08.016980

Qiao, Y., Halberg, N., Vaheesan, S., $\&$ Scott, S. (2016). Assessing the social and economic benefits of organic and fair trade tea production for small-scale farmers in Asia: A comparative case study of China and Sri Lanka. Renewable Agriculture and Food Systems, 31(3), 246257.

https://doi.org/10.1017/S174217 0515000162

Rahmawati, A., De Neve, S., \& Purwanto, B. H. (2015). N2O-N
Emissions from Organic and Conventional Paddy Fields from Central Java, Indonesia. Procedia Environmental Sciences, 28(SustaiN 2014), 606-612.

https://doi.org/10.1016/j.proenv. 2015.07.071

Rasul, G., \& Thapa, G. B. (2004). Sustainability of ecological and conventional agricultural systems in Bangladesh: An assessment based on environmental, economic and social perspectives. Agricultural Systems, 79(3), 327-351. https://doi.org/10.1016/S0308521X(03)00090-8

Rotar, P. P., \& Joy, R. J. (1983). “TROPIC SUN" SUNN HEMP Crotalaria juncea L . College of Tropical Agriculture and Human Resources, November, $1-11$.

Slamet, A., Nakayasu, A., \& Bai, H. (2016). The Determinants of Organic Vegetable Purchasing in Jabodetabek Region, Indonesia. Foods, $\quad 5(4), \quad 85$. https://doi.org/10.3390/foods50 40085

Vasile, A. J., Popescu, C., Ion, R. A., \& Dobre, I. (2015). From conventional to organic in Romanian agriculture - Impact assessment of a land use changing paradigm. Land Use Policy, 46, 258-266. https://doi.org/10.1016/j.landuse pol.2015.02.012

Wynn, G., Crabtree, B., \& Potts, J. (2008). Modelling Farmer Entry 
into the Environmentally Sensitive Area Schemes in Scotland. Journal of Agricultural Economics, 52(1), 65-82. https://doi.org/10.1111/j.14779552.2001.tb00910.x
Zulfiqar, F., \& Thapa, G. B. (2017). Agricultural sustainability assessment at provincial level in Pakistan. Land Use Policy, 68(February 2016), 492-502. https://doi.org/10.1016/j.landuse pol.2017.08.016

Zia, M. S., Khan, M. J., Qasim, M., \& Rahman, A. (2009). Pesticide residue in the food chain and human body inside Pakistan. Journal of the Chemical Society of Pakistan, 31(2), 284-291. 